\title{
PROPOSAL FOR CREATION OF POSITRON-EMISSION TOMOGRAPHY CENTER ON THE BASIS OF SCHOOL OF MEDICINE AND SCHOOL OF PHYSICS AND TECHNOLOGY OF KHARKIV NATIONAL UNIVERSITY
}

\author{
V.O. Voronko ${ }^{1}$, R.N. Dronov ${ }^{1}$, B.I. Shramenko ${ }^{1}$, I.V. Beloziorov ${ }^{2}$, I.O. Girka ${ }^{2}$ \\ ${ }^{1}$ National Science Center “Kharkov Institute of Physics and Technology”, Kharkiv, Ukraine; \\ ${ }^{2}$ V.N. Karazin Kharkiv National University, Kharkiv, Ukraine \\ E-mail: bshram@kipt.kharkov.ua
}

The creation of a PET center in the Kharkov region is proposed. This is facilitated by the transfer of the cyclotron by the Julich Research Center (Germany) to Kharkiv, which will ensure the development of the diagnostic radiopharmaceutical "Glucose ${ }^{18} \mathrm{~F}$ ". An additional expansion of the treatment base is possible by acquiring a microtron electron accelerator, which will make it possible to produce and use for treatment of cancer the "Ethanol, ${ }^{11}$ " radiopharmaceutical and the "Glucose, ${ }^{11} \mathrm{C}$ " diagnostic radiopharmaceutical developed at the NSC KIPT.

PACS: 87.57.uk, 87.57.un

\section{INTRODUCTION}

The proposal is an updated version of the Project [1] that was proposed earlier and has not been implemented due to the lack of radiopharmaceuticals for PET diagnostics and the PET tomograph itself. Given the absence of such a Center in the Kharkiv region, the need to create a Center for Positron Emission Tomography has not only lost its relevance, but has become even more urgent. At present, the situation with radiopharmaceuticals for PET diagnostics has been improved due to production in NSC KIPT of ready to use radiopharmaceuticals labeled with the ${ }^{11} \mathrm{C}$ isotope: "Glucose, ${ }^{11} \mathrm{C}$ " $[2,9]$, and "Ethanol, ${ }^{11} \mathrm{C}$ " [3].

The ${ }^{11} \mathrm{C},{ }^{13} \mathrm{~N},{ }^{15} \mathrm{O}$, and ${ }^{18} \mathrm{~F}$ isotopes, which form the basis of radiopharmaceuticals for PET diagnostics, have short half-lives: from $2 \mathrm{~min}\left({ }^{15} \mathrm{O}\right)$ to $110 \mathrm{~min}\left({ }^{18} \mathrm{~F}\right)$. For this reason, the main condition for the implementation of the Proposal is the need to locate the PET in the immediate vicinity of the isotope and radiopharmaceutical production site.

\section{ESSENCE OF PROPOSAL}

The condition of close proximity of accelerators where pharmaceuticals produced and PET scanner, where pharmaceuticals is used, is well met by this proposal. According to proposal, accelerators, which are used to obtain the pharmaceuticals labeled with ${ }^{11} \mathrm{C}$ and ${ }^{18} \mathrm{~F}$ isotopes, will be placed in a building that belongs to school of physics and technology of Kharkiv National University. The PET is planned to be placed in the building of Kharkiv Specialized Medical Unit № 13, which is only 134 meters away (in the line of sight). The production of ${ }^{18} \mathrm{~F}$ isotopes, "Fludeoxyglucose, ${ }^{18} \mathrm{~F}$ " will be performed on the accelerator of protons (cyclotron) and isotopes ${ }^{11} \mathrm{C}$ (radiopharmaceuticals "Glucose, ${ }^{11} \mathrm{C}$ " $[2,9]$ and "Ethanol, ${ }^{11} \mathrm{C}$ " [3]) will be produced on electron accelerator - microtron MM50 Scanditronix.

This will allow for the rapid transportation of the generated isotopes from the accelerator to the PET using pneumatic tube system (PTS) (Fig. 1).

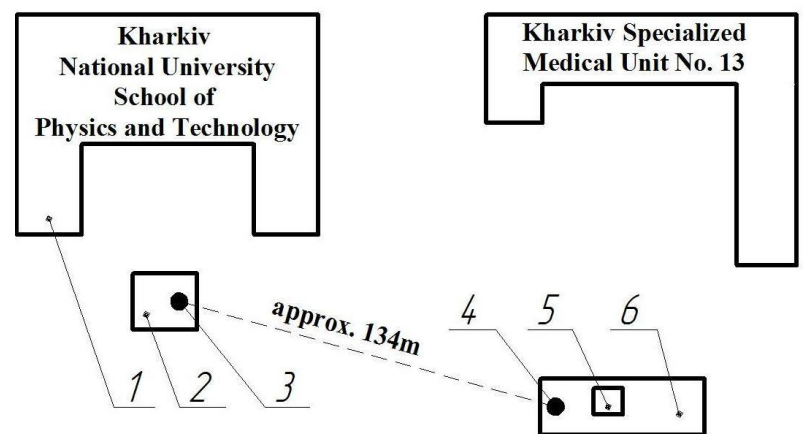

Fig. 1. Schematic location of the available buildings involved in Proposition:

1 - Building of KhNU's School of Physics and Technology; 2 -Vault; $7 \mathrm{~m}$ below ground level where accelerators (cyclotron/microtron) should be installed;

3 - Place where ampoule (A) with isotopes or radiopharmaceutical is loaded into the PTS; 4 -Place near the PET where ampoule (A) is unloaded from PTS for final preparation of radiopharmaceutical (if necessary); 5 -PET; 6-Building for PET and patient care rooms

Transport of the ampoule (A) between positions 3 and 4 to a distance of $134 \mathrm{~m}$ is accomplished by pneumatic tube system and takes approximately one minute. The aerial view of the available buildings involved is shown in Fig. 2.

One of the important factors that will contribute to the implementation of the Proposal is the successful implementation in practice of NSC KIPT the possibility of obtaining new radiopharmaceuticals labeled with ${ }^{11} \mathrm{C}$ isotope ready for use for PET diagnosis and treatment. The development of new radiopharmaceuticals is described in patent applications [2, 3] and radiopharmaceutical "Glucose, ${ }^{11} \mathrm{C}$ " in [9] correspondingly.

It is important that the invention [3] significantly improve the method proposed by American scientists in the treatment of cancer with ethanol (alcohol) [4, 5]. These researchers believe that even one injection of ethanol-based gel can cure certain types of tumors, and that some cancers of the cervix and breast cancer can be treated. 


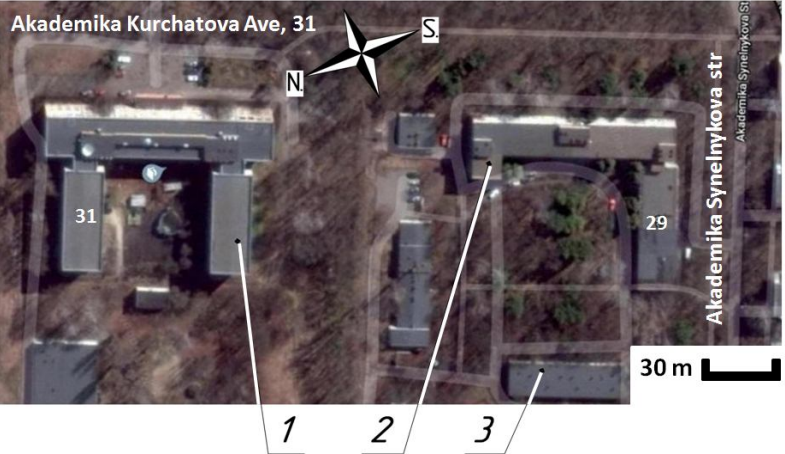

Fig. 2. The aerial view of the buildings involved in Proposition (Source: Google Maps).

1 - Building of KhNU's School of Physics and Technology; 2 - Main building of Kharkiv Specialized Medical Unit № 13;3 - Building for PET and patient care rooms

Our improvement in cancer treatment $[4,5]$ consists of the labeling of ethyl alcohol with ${ }^{11} \mathrm{C}$ isotope (i.e., the creation of a new radiopharmaceutical "Ethanol, ${ }^{11} \mathrm{C}$ " [3]), which enables PET imaging to visualize the location and spatial shape of the ethanol introduced into the tumor. The use of "Ethanol, ${ }^{11} \mathrm{C}$ " provides continuous dynamic control over the cancer treatment process with ethanol and the possibility of additional corrective injections of ethanol, if necessary.

The timely implementation of the Proposal will open wide opportunities for cancer treatment in Ukraine without a significant time gap from the US.

As the new method of treating cancer with ethanol $[4,5]$ is only beginning to develop, the timely implementation of the Proposal will help close the huge gap that exists today between cancer treatment options in Ukraine and in developed countries.

In addition, the implementation of the Proposal (as a pilot version) will make it possible to test in practice the efficiency and effectiveness of the complexes of the PET diagnostic system, their functionality and the correctness of the conceptual approaches that underlie the Proposal, in order to take into account the acquired experience for further improvement, development of PET - cancer treatment centers in Ukraine.

The implementation of the Proposal includes two stages:

\section{STAGE I (Year 2021)}

Provides PET diagnostics with the use of "Fludeoxyglucose,${ }^{18} \mathrm{~F}$ " obtained on a proton accelerator, a cyclotron, using well-developed (licensed) worldwide technology.

1. Installation and commissioning of cyclotron (baby cyclotron)*. Building 1 (vault 2) (see Fig. 1).

2. Design and construction of the pneumatic tube system (see Fig. 1).

3. Installation of PET** in Building 6 (see Fig. 1), (Building 3 (see Fig. 2).

4. Development of complex functioning - PET diagnostic center.

*Cyclotron will be delivered from the Jülich Science Center (Germany) according to an existing agreement.

**Obtaining PET from structures interested in the use of radiopharmaceuticals that will be based on a cy- clotron (under existing arrangement), or purchasing a PET following the example of a PET center in Kyiv (Feofaniya).

\section{STAGE II (Years 2021-2022)}

Provides practical implementation of the method of cancer treatment with ethanol by the method $[4,5]$ taking into account improvements [3] ("Ethanol, ${ }^{11} \mathrm{C}$ "), as well as the provision of PET diagnostics, using the traditional radiopharmaceutical "Fludeoxyglucose ${ }^{18} \mathrm{~F}$ " and the new radiopharmaceutical "Glucose, ${ }^{11} \mathrm{C}$ " $[2,9]$, which provides receptor (repeat) studies. Glucose, ${ }^{11} \mathrm{C}$ and Ethanol, ${ }^{11} \mathrm{C}$ will be developed on the MM-50 (Scanditronix) ${ }^{* * *}$ electron microtron accelerator, which is selected as an electron source due to its reliability and ease of use (in addition, a microtron is cheaper than a linear accelerator).

1. Installation and commissioning MM-50 microtron with $30 \ldots 50 \mathrm{MeV}$ energy and average current of $10 \ldots 20 \mu \mathrm{A}$.

2. Practical preparation and use of the pharmaceutical "Ethanol, ${ }^{11} \mathrm{C}$ " [3] for the treatment of cancer with ethanol by the method $[4,5]$ in combination with PET diagnostics.

3. Practical preparation and use of the pharmaceutical "Glucose, ${ }^{11} \mathrm{C}$ " $[2,9]$ for PET diagnostics, including frequently repetitive studies using PET.

***The acquisition of the MM-50 microtron (Scanditronix) overseas is planned.

Factors that will contribute to the implementation of the Proposal:

- the specialized vault of the KhNU, where accelerators are to be installed, has all the relevant permits for operating the accelerators in the modes planned by this Proposal;

- the use of existing buildings for PET and accelerators significantly reduces the timeframe for the implementation of the Proposal;

- the location of the PET in close proximity to the isotope production site greatly simplifies its implementation and, most importantly, enables it to maintain the accumulated level of ultra short lived isotope's activity by transporting it via pneumatic tube system to the radiopharmaceutical preparation site (near PET);

- the availability of qualified personnel of NSC KIPT and those of School of Physics and Technology of the KhNU, whose participation will ensure the implementation of the Proposal, will help to ensure the constant development of isotopes ${ }^{18} \mathrm{~F}$ and ${ }^{11} \mathrm{C}$ and preparation of radiopharmaceutical based on them for PET diagnosis and treatment [2, 3, 6 - 9];

- participation of medical staff of the Grigoriev Institute for Medical Radiology (as provided by the Proposal), who has experience in the field of nuclear medicine, with additional involvement in the practice and work of students of the School of Medicine, as well as the Department of Nuclear and Medical Physics of the School of Physics and Technology of KhNU;

- an important factor that will contribute to the implementation of the proposal for the creation of the Center (as an additional training base) may be the training of young people at the School of Physics and Technol- 
ogy of KhNU under the already accredited educational program "Medical Physics";

- the availability of proven methods of obtaining radiopharmaceuticals "Glucose, ${ }^{11} \mathrm{C}$ " and "Ethanol, ${ }^{11} \mathrm{C}$ " on the electron accelerator of the NSC KhIPT [2, 3, 9].

Executing organizations to be involved in the implementation of the Proposal:

1. National Science Center "Kharkov Institute of Physics and Technology".

2. Karazin Kharkiv National University. (School of Physics and Technology, School of Medicine).

3. Grigoriev Institute for Medical Radiology.

\section{CONCLUSIONS}

1. Implementation of Stage I of the Proposal will give the opportunity to provide Kharkiv region with a standard Center for PET diagnostics. Under favorable conditions (free delivery of cyclotron (baby cyclotron) and PET tomograph), the cost of Stage I will be determined only by the cost of licensed technology of creation of radiopharmaceutical "Fludeoxyglucose, ${ }^{18} \mathrm{~F}$ " and the cost of construction of the pneumatic tube system. For this reason, Stage I takes relatively modest funding and deserves careful attention.

2. The implementation of Stage II will create the world's first, unique PET Center with the possibility of treating cancer with the new radiopharmaceutical "Ethanol, ${ }^{11}$ C" [3], which was developed by NSC KIPT after research by the American researchers on cancer treatment using conventional ethanol $[4,5]$. The cost of this stage will be determined by the cost of the MM-50 microtron (Scanditronix).

3. The fulfillment of the Proposal does not require costly and long-term capital construction of buildings for PET and accelerators, which significantly shortens the Proposal's implementation time.

4. The complementary nature of the above factors, including the territorial proximity, administrative and organizational subordination of Proposal's participants, as well as the scientific and ideological interest of scientific and medical institutions in achieving the ultimate goal, will contribute to the practical implementation of this Proposal.

\section{ACKNOWLEDGEMENT}

The authors express their sincere thanks for the assistance and helpful comments when discussing the Proposal to:

M.F. Shulga - Director General of NSC KIPT NAS;

M.V. Krasnoselsky - Director of Grigoriev Institute for Medical Radiology;

V.P. Starenky - Head of the Department of Radiation Therapy of Grigoriev Institute for Medical Radiology;
M.V. Kolomensky - Head of Kharkiv Specialized Medical Unit № 13;

V.G. Rudichev - Leading researcher of the School of Physics and Technology of KhNU.

\section{REFERENCES}

1. A.M. Dovbnya, M.P. Dykyy, A.S. Zadvornyy, O.H. Konovalov, M.I. Pylypenko, P.V Sorokin, B.I. Shramenko. Proekt Pivnichno-Skhidnoho rehionalnoho Tsentru pozytron-emisiynoyi tomohrafiyi // URZH. 1999, № 7, p. 316-317 (in Ukrainian).

2. A.M. Dovbnya, B.I. Shramenko. Sposib oderzhannya radiofarmpreparatu $« H l y u k o z a,{ }^{11} \mathrm{C} »$ dlya diahnostyky iz zastosuvannya pozytron-emisiynoyi tomohrafiyi. Patent Ukrayiny № 118509 vid 25.01.2019 r. (in Ukrainian).

3. A.M. Dovbnya, B.I. Shramenko. Radiofarmpreparat $z$ izotopom ${ }^{I l} C$ ta sposib yoho otrymannya. Patent Ukrayiny № 120321.vid 11.11.2019 r. (in Ukrainian).

4. Markus Schober, and Elaine Fuchs, Rockefeller University. New Low-Cost Cancer Treatment Could Kill Tumors With Ethanol // Nature Scientific Reports, Sept. 2017. (https://futurism.com/ new-lowcost-cancer-treatment-could-kill-tumors-withethanol/).

5. R. Morhard, et al. Development of enhanced ethanol ablation as an alternative to surgery in treatment of superficial solid tumors // Scientific Reports 7, Article number 8750. Published:18-Aug2017.doi:10.1038/s41598-017-09371-2 PMCID: PMC5562881 PMID: 28821832.

6. M.I. Ayzatskyy, Ye.Z. Biller, V.N. Boryskin, M.P. Dykyy, B.I. Shramenko ta inshi. Rozrobka v NSC KIPT fotoyadernoyi tekhnolohiyi vyrobnytstva medychnykh radionuklidiv // URZH. 2007, № 2, p. 221-223 (in Ukrainian).

7. M.I. Ayzatskyy, N.P. Dykyy, A.N. Dovbnya, Yu.V. Lyashko y dr. Oderzhannya Cu-67 bez nosiya na pryskoryuvachi elektroniv // URZH. 2007, № 2, p. 223-227 (in Ukrainian).

8. A.I. Azarov, A.N. Dovbnya, M.A. Dolzhec, et al. About the use in nuclear medicine of pharmaceuticals on the basis of the isotope ${ }^{18} \mathrm{~F}$ and its achievements on linear electron accelerators of NIK "Accelerator" // Problems of Atomic Science and Technology. Series "Nuclear Physics Investigations". 2017, № 6, p. 133-136.

9. A.N. Dovbnya, R.N. Dronov, V.A. Kushnir, et al. Production of ${ }^{11} \mathrm{C}$ and ${ }^{18} \mathrm{~F}$ isotopes. Getting the "Glucose, ${ }^{11} \mathrm{C}$ " radiopharmaceutical // East European Journal of Physics (EEJP). 2018, v. 5, № 4, p. 7786.

Article received 28.02.2020 


\section{ПРЕДЛОЖЕНИЕ ПО СОЗДАНИЮ ЦЕНТРА ПОЗИТРОН-ЭМИССИОННОЙ ТОМОГРАФИИ НА БАЗЕ МЕДИЦИНСКОГО И ФИЗИКО-ТЕХНИЧЕСКОГО ФАКУЛЬТЕТОВ ХНУ}

\section{В.А. Воронко, Р.Н. Дронов, Б.И. Шраменко, И.В. Белозёров, И.А. Гирка}

Предложено создание в Харьковском регионе ПЭТ-центра. Этому способствует передача Юлихским научным центром (Германия) в г. Харькове циклотрона, который обеспечит наработку диагностического радиофармпрепарата «Глюкоза, ${ }^{18} \mathrm{~F}$. Дополнительное расширение лечебной базы возможно путем приобретения ускорителя электронов микротрона, который даст возможность производить и использовать для лечения рака радиофармпрепарат «Этанол, ${ }^{11} \mathrm{C} »$, а также диагностический радиофармпрепарат «Глюказа, ${ }^{11} \mathrm{C} »$, разработанные в ННЦ ХФТИ.

\section{ПРОПОЗИЦІЯ ЗІ СТВОРЕННЯ ЦЕНТРУ ПОЗИТРОН-ЕМІСІЙНОЇ ТОМОГРАФІЇ НА БАЗІ МЕДИЧНОГО ТА ФІЗИКО-ТЕХНІЧНОГО ФАКУЛЬТЕТІВ ХНУ}

\section{В.О. Воронко, Р.М. Дронов, Б.І. Шраменко, І.В. Белозьоров, І.О. Гірка}

Запропоновано створення в Харківському регіоні ПЕТ-центру. Цьому сприяє передача Юліхським науковим центром (Німеччина) у м. Харків циклотрона, який забезпечить напрацювання діагностичного радіофармпрепарата «Глюкоза, ${ }^{18} \mathrm{~F}$ ». Додаткове розширення лікувальної бази можливо шляхом придбання прискорювача електронів мікротрона, який дасть можливість виробляти і використовувати для лікування раку радіофармпрепарат «Етанол, ${ }^{11} \mathrm{C}$, а також діагностичний радіофармпрепарат «Глюкоза, ${ }^{11} \mathrm{C}$, розроблені в ННЦ ХФТІ. 